\title{
Doctor Mobile System for Data Visualization
}

\author{
Zainab Pirani, PhD \\ M. H. Saboo Siddik College of \\ Engineering \\ 8, Saboo Siddik Polytechnic \\ Road, Byculla, Mumbai, \\ Maharashtra 400008
}

\author{
Jawad Shaikh \\ M.H Saboo Siddik College of \\ Engineering \\ 8, Saboo Siddik Polytechnic \\ Road, Byculla, Mumbai, \\ Maharashtra 400008
}

\author{
Rishabh Masani \\ M.H Saboo Siddik College of \\ Engineering \\ 8, Saboo Siddik Polytechnic \\ Road, Byculla, Mumbai, \\ Maharashtra 400008
}

\author{
Maaz Khan \\ M.H Saboo Siddik College of Engineering \\ 8, Saboo Siddik Polytechnic Road, Byculla, \\ Mumbai, Maharashtra 400008
}

\author{
Afzal Sayed \\ M. H. Saboo Siddik College of Engineering \\ 8, Saboo Siddik Polytechnic Road, Byculla, \\ Mumbai, Maharashtra 400008
}

\begin{abstract}
The role of Information Technology is vital in all the sectors. It has made a significant impact even on the healthcare sector all around the world. Still they are using the age old methods and techniques as they have not yet found a viable alternative. The project will try to understand the doctor's needs and come up with a solution that can be effortlessly integrated in their lives. This solution will help save a lot of their valuable time which can then be used in much better ways. The scope of the solution is to create an end - to - end system to benefit the doctors as well as the patients. It will be a mobile application and hence will be very easy to use. The system will be easily accessible by any doctor who wants to use it. The data collection part of the system will help the doctors in collecting valuable data about their patients. It will help them analyze and visualize all their patient history and various important and critical cases. It will in turn help them in drawing useful insights about their performance as well as understand the trends among their patients. The existing traditional approach of doctors involves a lot of manual work. Things like managing and allocating of appointments is handled by a receptionist. There are certain existing solutions which try to solve some of these problems and are discussed in detail during Literature Review. The solution primarily aims at orthopedic doctors and surgeons and will contain certain field specific functionalities.
\end{abstract}

\section{General Terms}

Data Analytics, Orthopedic, Doctor Mobile System.

\section{Keywords}

Analytics and Reporting, Goniometer, Orthopedic, Doctor and Patient Profile Storage.

\section{INTRODUCTION}

Many hospitals are very traditional in their outlook and refuse to use modern technology due to the fear of change. They even refuse to share data regarding their patients even with the patient's relatives. For effective and quick remedies, proper flow of information is essential between the doctors and their patients. Today, data has become an integral part of the society and even the healthcare industry has been affected by it. Numerous specialities are being introduced in the field by the hour. The concept of information explosion has become a reality in the healthcare industry. Collecting and making sense of this information is the emergent need. The aim is to accomplish the above tasks by creating a system that manages all the data flow between the doctors and the patients.

\section{EXISTING SYSTEMS}

The existing traditional approach of doctors involves a lot of manual work. Things like managing and allocating of appointments is handled by a receptionist. The managing of various patients critical medical records like X-rays is often directly handled by the doctor. The doctor has to do a manual work if the doctor wants to sort the patient record in a particular order, eg: If the doctor wants a list of all patients with left hand fracture, then the doctor has to manually check all the X-rays and segregate all the patients with left hand fracture. All orthopedic doctors use a goniometer to measure angles in $\mathrm{X}$ rays, to do that the doctors manually draw the X-ray on paper and then measure the angles. This is a time consuming process.

\subsection{Practo [1]}

Practo Ray was the first SaaS product the company launched in India.The role of information technology is vital in all the sectors.The ultimate objective of Practo is to offer a holistic service for the patients to reach the right doctor at the right time at the right place.

\subsection{Mobile IT Solutions for Home Health Care [2]}

Rudiger with the purpose of Harnessing the merits of mobile information technology (IT) solutions with a view to contribute to patients' safety by linking them applied case study analysis and came out with a conclusion that the user-friendly handy IT applications going beyond documentation of patient records and management necessitate an understanding of intricate communication processes between patients and the different caregivers.Home care increasingly faces structural deficits to be mitigated by integration of IT solutions.

\subsection{Assessing Health Information Technology in a National Health Care System [3]}

Chunhuei observed the practice of Health Information Technology (HIT) in reviewing the national health care system in Taiwan. They used the following five criteria for the purpose of the study. How well does the HIT

(1) Supply reachable and exact public health and health care information to the population; (2) Gather and offer population health and health care data for 
government and researchers to investigate population health and processes and outcomes of health care services; (3) Present handy and apt information that helps to develop provision of cost-effective health care at an institutional level and promotes system-wide efficiency; (4) Reduce transaction and administrative costs of the healthcare

system;

(5) Create channels for population participation in governance while also protecting individual privacy.

The outcome points out that Taiwan has high levels of achievement in two criteria while falling short in the other three.Major lessons learnt from this study are that HIT exists to serve a health care system, and the national health care system context dictates how one assesses its HIT.

\subsection{Implementing a Regional Health}

\section{Information Network [4]}

The re-organization of health care systems involves interconnected changes and the development of integrated health care information The paper concludes with policy and practice recommendations for managing change processes in health care organizations

\subsection{An e-health trend plan for the Jordanian health care system [5]}

The objective is to scrutinize the potential of e- health by focusing clearly on the delivery of health care products and services, by one extensive research question, "What is the potential for constructing e- health strategy as an innovative health technology?" This paper reviews the e- health trends to demonstrate the tremendous potential for health- related commercial activity on the internet.

\section{PROPOSED SYSTEM}

Table 1: Doctor specific requirements

\begin{tabular}{|c|c|c|c|c|}
\hline $\begin{array}{l}\text { Sr. } \\
\text { No. }\end{array}$ & Questions & Dr. Wasim & Dr. Mohit Jain & Dr. Naved \\
\hline 1 & $\begin{array}{l}\text { Are there any mobile application tion } \\
\text { that is being already used by the } \\
\text { orthopedic doctors and that gives then } \\
\text { above features? }\end{array}$ & Not that I know & $\begin{array}{l}\text { Practo, Justdial, } \\
\text { Linkedin }\end{array}$ & None that I know \\
\hline 2 & $\begin{array}{l}\text { Would doctors prefer to make use of } \\
\text { such an application and will it benefit } \\
\text { them? }\end{array}$ & Yes & Yes & $\begin{array}{l}\text { Yes. It will benefit them. } \\
\text { Provided it has a good } \\
\text { assurance that the data } \\
\text { will be saved and } \\
\text { services are provided } \\
\text { continuously. }\end{array}$ \\
\hline 5 & $\begin{array}{l}\text { Would you want to create a profile of } \\
\text { a patient and keep a medical history of } \\
\text { the patient? What would be the } \\
\text { minimum data that you would like to } \\
\text { enter for the patient for creating a } \\
\text { profile? }\end{array}$ & $\begin{array}{l}\text { Yes I would like to } \\
\text { create a profile min data } \\
\text { name age sex \& contact } \\
\text { details }\end{array}$ & $\begin{array}{l}\text { Yes. Name, Age, } \\
\text { Location, Diagnosis } \\
\text { (Fracture, Shoulder } \\
\text { injury etc.), } \\
\text { Complication(Any new } \\
\text { Infection) }\end{array}$ & $\begin{array}{l}\text { I suggest the patient } \\
\text { makes the profile } \\
\text { himself. }\end{array}$ \\
\hline 6 & $\begin{array}{l}\text { If an app provide you a feature, where } \\
\text { you can click images of diseases/state } \\
\text { of the patient for future needs, would } \\
\text { you use it? And how will that be } \\
\text { beneficial? } \\
\text { Would you want to link the clicked } \\
\text { images to patient history? }\end{array}$ & $\begin{array}{l}\text { Would be beneficial for } \\
\text { academic and medico } \\
\text { legal purpose and also } \\
\text { for follow up visits }\end{array}$ & $\begin{array}{l}\text { Yes would be very } \\
\text { beneficial. To check the } \\
\text { progress and academic } \\
\text { purposes. }\end{array}$ & It is good. \\
\hline 7 & $\begin{array}{l}\text { What other features do you expect } \\
\text { from such an app? }\end{array}$ & & $\begin{array}{l}\text { Must be implemented on } \\
\text { PC and lite version on } \\
\text { mobile. }\end{array}$ & \\
\hline 8 & $\begin{array}{l}\text { Even if all these features are available, } \\
\text { will the doctors use the app keeping } \\
\text { time consumption in mind. }\end{array}$ & Yes they should use it & Yes & $\begin{array}{l}\text { Cannot say. There's } \\
\text { always a risk of losing } \\
\text { all the data if the app } \\
\text { closes its services }\end{array}$ \\
\hline
\end{tabular}




\begin{tabular}{|c|c|c|c|c|}
\hline 9 & $\begin{array}{l}\text { Would you be interested to have a } \\
\text { calendar in the app that you can share } \\
\text { with your patients so that they know } \\
\text { which clinic/hospital will you visit } \\
\text { and when? }\end{array}$ & Yes & $\begin{array}{l}\text { Yes. It will be used to } \\
\text { show Holiday markings } \\
\text { and schedule of doctor }\end{array}$ & No. \\
\hline 10 & $\begin{array}{l}\text { How do the patients communicate to } \\
\text { you and request appointments? Would } \\
\text { you want to do this electronically? }\end{array}$ & $\begin{array}{l}\text { However I would not } \\
\text { prefer electronic } \\
\text { appointment }\end{array}$ & $\begin{array}{l}\text { Through app its fine but } \\
\text { its human nature to } \\
\text { confirm through call } \\
\text { first, before arriving. }\end{array}$ & $\begin{array}{l}\text { Either through phone or } \\
\text { directly coming to the } \\
\text { hospital. }\end{array}$ \\
\hline 11 & $\begin{array}{l}\text { What more can be implement so that it } \\
\text { helps increase doctors practice apart } \\
\text { from being organized? }\end{array}$ & & $\begin{array}{l}\text { Goniometer app. Where } \\
\text { doctor can measure } \\
\text { angles in x-ray or } \\
\text { fracture report.(Very } \\
\text { important for every } \\
\text { orthopedic) }\end{array}$ & $\begin{array}{l}\text { Make the app such that } \\
\text { even if the app stops in } \\
\text { between it does not } \\
\text { affect the doctor. The } \\
\text { data must not be lost }\end{array}$ \\
\hline 12 & $\begin{array}{l}\text { Would an online payment system } \\
\text { inbuilt in app be a good idea? }\end{array}$ & No & $\begin{array}{l}\text { No. If you provide an } \\
\text { instant swipe facility } \\
\text { like Paytm its fine. Else } \\
\text { the whole e-paying for } \\
400-600 \text { Rs. is not viable }\end{array}$ & No \\
\hline 13 & $\begin{array}{l}\text { Do you think to have examination } \\
\text { history in the app for each patient to } \\
\text { be updated so that patient can view it } \\
\text { anywhere anytime and can share it } \\
\text { with other doctors electronically? }\end{array}$ & No & $\begin{array}{l}\text { Yes. So that we can } \\
\text { compare previous week } \\
\text { x-ray with this week. }\end{array}$ & Yes. \\
\hline 14 & $\begin{array}{l}\text { Would it be a good idea to apply some } \\
\text { kind of discounts automatically to } \\
\text { frequent patients as per their visit or to } \\
\text { patients referred by other doctors? }\end{array}$ & No & $\begin{array}{l}\text { No. Follow up charges } \\
\text { are always less than the } \\
\text { initial charge within a } \\
\text { period of } 1-2 \text { months. }\end{array}$ & $\begin{array}{l}\text { No. Covered in follow } \\
\text { up charges. }\end{array}$ \\
\hline 15 & $\begin{array}{l}\text { Would it be a good idea to build a } \\
\text { referral system in the background if } \\
\text { the patient has been referred by } \\
\text { Doctor ABC then the Dr. ABC gets a } \\
\text { referral provision? }\end{array}$ & & $\begin{array}{l}\text { No. The name of the } \\
\text { previous doctor comes } \\
\text { up anyways. It must not } \\
\text { be shown directly. }\end{array}$ & No. \\
\hline 16 & $\begin{array}{l}\text { The app can be used to generate } \\
\text { statistical reports like average time } \\
\text { taken to examine a patient, average } \\
\text { age of patients, peak time for visits or } \\
\text { days for visits etc. Will this be a } \\
\text { usable feature? }\end{array}$ & Yes it would be useful & $\begin{array}{l}\text { Yes. Will be beneficial. } \\
\text { Must show charts as per } \\
\text { age, disease, diagnosis, } \\
\text { complication etc. } \\
\text { Peak time, average time } \\
\text { not useful. Age, location } \\
\text { and disease very useful. }\end{array}$ & Yes. This will be useful. \\
\hline
\end{tabular}

Based on the requirements received from the doctors, the system will include the following points

1. Creates a profile for patients and doctors.

2. Allow users to rate the doctors which contributes to the overall rating of the doctor.

3. Enable patient to add appointment events into the his/her timeline. Each event consisting of two parts, patient's self diagnosis and doctor's evaluation.

4. Provides a database that is always in sync locally so that the device need not be online to fetch data.
5. Provides a goniometer feature to the doctors to carry out measurements effectively covered in upcoming updates.

6. Provide various options to the user for exporting the data into suitable formats like an excel sheet.

7. Provide analytics and data visualization to the user by collecting data from the appointment events in the timeline. Goals will be accomplished in two phases -

\subsection{Phase 1}

In this phase the main motive of the system would be to collect 
data while helping the doctors as well as the patients. The data analytics services won't be available in this phase as there would be no data to perform the analytics. The system will be performing most of the functionalities it promises at this stage except for the data analytics and report generation. As new patients and doctors start signing up and using the app, appropriate data would be available for phase 2 .

\subsection{Phase 2}

In this phase, the system will build upon the data collected in
Phase-1 and additional features will be introduced. These features will include patient data analytics, data visualization and customized report generation. A survey carried out revealed that a lot of orthopedicians want these features as it would aid them in their research work. Proper aggregation and visualization of a patient's past medical records will greatly help the doctors in reaching concrete conclusive decisions swiftly and confidently. The doctors will then don't have to worry about the data and hence would get more time to focus on making the right deductions from the data.

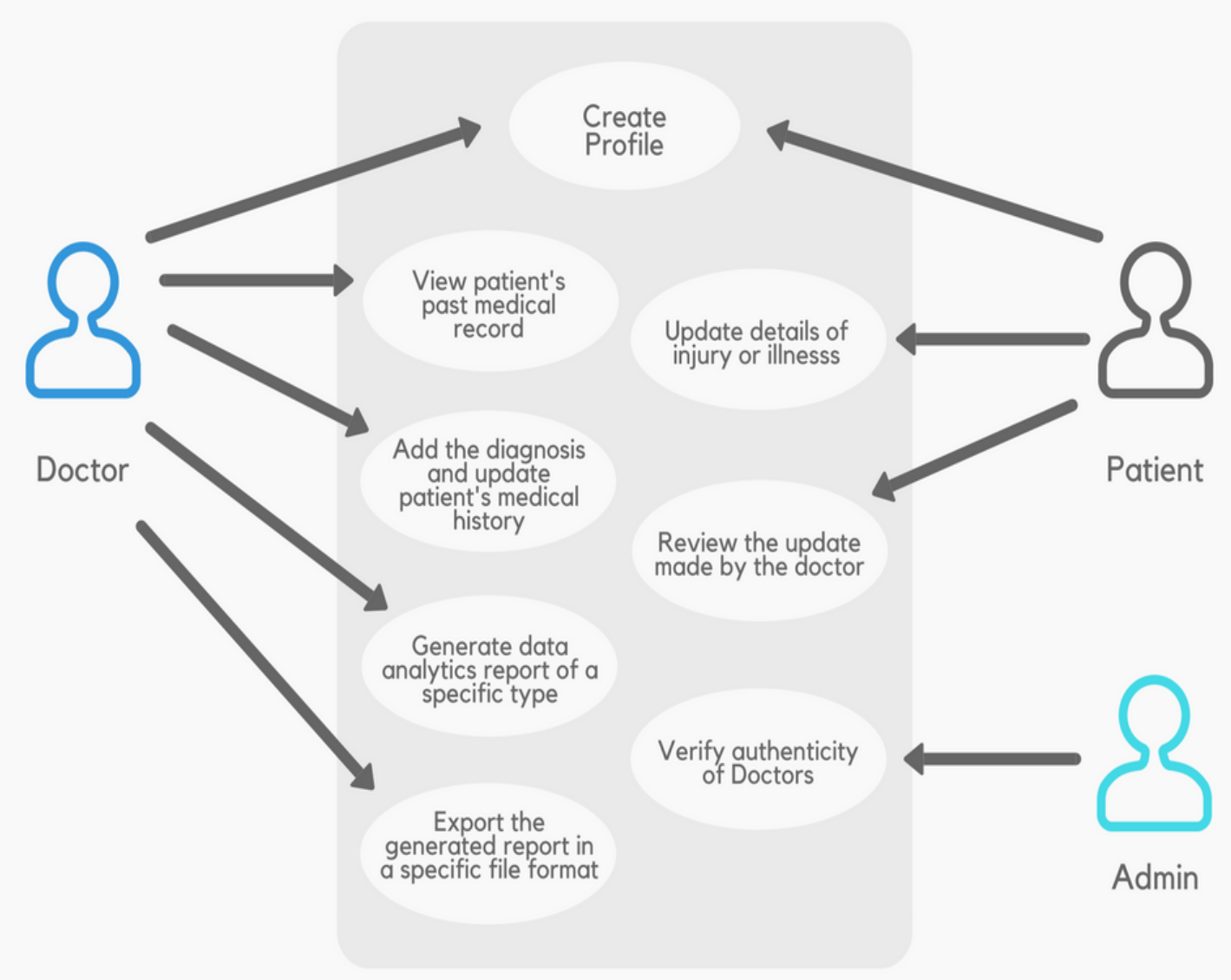

Figure 1: Use case diagram

\section{CONCLUSION}

The primary goal of the system is to collect the wealth of data in the healthcare industry that is currently going unnoticed.. The proposed system has a lot of room for modifications and future scope which can be exploited constructively to put forth a system that can tackle doctor and patient records beyond the boundaries of nations. The proposed system can be made to work on a database that is distributed across the globe using concept of Distributed database. This will make the system more dynamic. The further updates will also have a desktop supported version so that the doctors can easily sync their work and use it according to their needs with ease. Doing this allows us to create actionable insights pertaining to the medical industry. These insights have the effect of helping the doctors in their day-to-day activities.

\section{REFERENCES}

[1] S. Gayathry* Assistant Professor-SRM B School, SRM University, Vadapalani, Chennai, Tamil Nadu, India., "Practo: Is it a Healthy Prescription for Indian HealthCare Industry?" *Corresponding author's E-mail: gayathry69@gmail.com ISSN 0976 - 044X

[2] Rüdiger Breitschwerdt, Rick Iedema, Sebastian Robert, Alexander Bosse, Oliver Thomas. Mobile IT Solutions for Home Health Care, in Nir Menachemi, Sanjay Singh (ed.) Health Information Technology in the International Context (Advances in Health Care Management), Emerald Group Publishing Limited, Volume 12, 2012, 171-187. DOI 10.1108/S1474-8231(2012)0000012012

[3] Chunhuei Chi, Jwo-Leun Lee, Rebecca Schoon. Assessing Health Information Technology in a National Health Care System - An Example from Taiwan, in Nir Menachemi, 
Sanjay Singh (ed.) Health Information Technology in the International Context (Advances in Health Care Management), Emerald Group Publishing Limited, Volume 12, 2012, 75-109. DOI 10.1108/S14748231(2012)0000012008

[4] Manolis Tsiknakis, Angelina Kouroubali, Dimitris Vourvahakis, Stelios C. Orphanoudakis. Implementing a Regional Health Information Network: Impact on Health

[5] Care Performance and the Management of Change, in Grant T. Savage, Jon A. Chilingerian, Michael Powell, Qian Xiao (ed.) International Health Care Management (Advances in Health Care Management), Emerald Group

\section{Publishing Limited, Volume}

[6] 2005, 297-329. 5. Ali Ahamd Awad Rawabdeh. "An e-health trend plan for the Jordanian health care system: a review", International Journal of Health Care Quality Assurance, Vol. 20, Iss: 6, 2007, 516-531. http://dx.doi.org/10.1108/09526860710819459

[7] Kenneth J. Trimmer, Lela D. "Kitty" Pumphrey, Carla Wiggins. "ERP implementation in rural health care", Journal of Management in Medicine, Vol. 16, Iss: 2/3, 2002 ,

$113-132$. 